\title{
Determination of Water Quality Parameters and Heavy Metal Content in Surface Water of Çiğdem Pond (Kastamonu/Turkey)
}

\author{
Aslı Kurnaz ${ }^{*}$, Ekrem Mutlu², Arzu Aydin Uncumusaoğlu \\ ${ }^{1}$ Departments of Physics, Faculty of Science and Letters, Kastamonu University, 37150 Kastamonu, Turkey \\ ${ }^{2}$ Departments of Aquaculture, Faculty of Fisheries, Kastamonu University, 37150 Kastamonu, Turkey \\ ${ }^{3}$ Departments of Environmental Engineering, Faculty of Engineering, Giresun University, 28200 Giresun, Turkey \\ A R T I C L I N F O \\ Article history: \\ Received 08 August 2016 \\ Accepted 26 August 2016 \\ Available online, ISSN: $2148-127 \mathrm{X}$ \\ Keywords: \\ Water quality \\ Heavy metal \\ Seasonal variation \\ Surface water \\ Çiğdem pond \\ "Corresponding Author: \begin{abstract}
A B S T R A C T
The main aims of this study were to observe the seasonal variations of physicochemical parameters and heavy metal content, to determine the water quality properties and the suitability level in terms of aquatic life, and also to classify the quality of water in accordance with the Surface Water Quality Management Regulation (SWQMR) criteria at Çiğdem Pond (Kastamonu/Turkey). In total, 21 physicochemical parameters and 7 heavy metals were investigated for water quality assessment of the studied pond between July 2015 and June 2016 in 3 stations. The water quality in Çiğdem Pond was found to be Class I according to SWQMR. The results of this study provide a data baseline for future studies on subsequent evaluations of possible future environmental contamination. Also, to protect the water quality and to ensure the health of aquatic life in this area, it is required to make regular observations.
\end{abstract}

E-mail: akurnaz@kastamonu.edu.tr

Türk Tarım - Gıda Bilim ve Teknoloji Dergisi, 4(10): 907-913, 2016

\section{Yüzey Suyundaki Su Kalitesi Parametreleri ve Ağır Metal İçeriğin Belirlenmesi}

M A K A L E B İ L G İ S İ
Geliş 08 Ağustos 2016
Kabul 26 Ağustos 2016
Çevrimiçi baskı, ISSN: 2148-127X
Anahtar Kelimeler:
Su kalitesi
Ağır metal
Mevsimsel değişim
Yüzey suyu
Çiğdem göleti

"Sorumlu Yazar:

E-mail: akurnaz@kastamonu.edu.tr
Ö Z E T

\begin{abstract}
Bu çalışmanın temel amaçları, Çiğdem Göleti'nde (Kastamonu-Türkiye) fizikokimyasal parametreler ve ağır metal içeriğin mevsimsel değişimini gözlemlemek, su kalitesi özelliklerini ve sucul yaşam açısından uygunluk seviyesini belirlemek ve ayrıca su kalitesini Yüzeysel Su Kalitesi Yönetimi Yönetmeliğine göre sinıflandırmaktır. Çalışmanın yürütüldüğü göletin su kalitesinin değerlendirilebilmesi için, Temmuz 2015 ve Haziran 2016 tarihleri arasında, 3 istasyonda toplam 21 fizikokimyasal parametre ve 7 ağır metal incelenmiştir. Sonuçta Çiğdem Göleti'ndeki su kalitesi, Yüzey Su Kalitesi Yönetimi Yönetmeliğine göre 1. sınıf olarak bulunmuştur. Ayrıca çalışma sonuçları, gelecekteki olası çevresel kirliliğinin değerlendirilmesi açısından ileriki çalışmalar için bir veri altyapısı sağlayacaktır. Bununla birlikte, su kalitesini korumak ve bu alanda sucul yaşamın sağlığını sağlamak için, düzenli gözlemler yapılması gerekmektedir.
\end{abstract}

\section{Introduction}

Water is one of the most important sources for life and the good quality water is essential for improving the quality of life. The rapid increase in population and increasing industrial, agricultural and forestry activities lead to significant affect in terms of amount, quality and usage of water. The only $2.5 \%$ of total water stock of the world is fresh water sources and the worldwide concern is that the good quality water may become a scarce resource in the near future (Anonymous, 2013; Debels et al., 2005). Because of these reason, the many countries have increased their interest in fresh water quality investigation during the past decades (Taş and Yılmaz, 2015; Kutlu et al., 2015; Shehu et al., 2016).
Heavy metals are the most common environmental pollutants, and their presence in the waters indicates the presence of natural or anthropogenic sources. In fact, heavy metals can occur naturally in the water, but rarely at toxic levels. The main natural sources of the heavy metals in fresh waters are weathering of rocks, soil leaching and dissolution of aerosol particles from the atmosphere. Heavy metal contamination refers to the excessive deposition of toxic heavy metals in the environment caused by human activities and the anthropogenic sources are associated mainly with industrial and domestic wastes and the increased use of 
metal based pesticides and fertilizer in agriculture (Debels et al, 2005; Papafilippaki et al., 2008; USDA, 2000).

The concentrations of some heavy metals are beneficial and essentially required for normal and normal body growth and functions of living organisms such as metal nutritional requirements $(\mathrm{Co}, \mathrm{Cu}, \mathrm{Fe}, \mathrm{Mn}, \mathrm{Ni}$ and $\mathrm{Zn})$. But, some heavy metals can cause biological toxicity, such as arsenic (As), cadmium (Cd), chromium $(\mathrm{Cr})$, lead $(\mathrm{Pb})$ and mercury $(\mathrm{Hg})$. Also the heavy metals and other physical and chemical parameters are easily affected from environmental factors such as surface runoff, groundwater and deposition from the atmosphere and anthropogenic pollutants. Thus, it is important to identify the quantifying of heavy metal concentrations and to monitor possible changes (Lawson, 2011; Asaolu et al., 1997).

Surface water pollution by heavy metals is increasingly common environmental problem all over the world (Khan et al., 2013; Wu et al., 2008) because the ponds and lakes are primarily affected from the pollution. The rapid changes in physical and chemical parameters of the surface waters lead to deterioration of the environment's balance in aquatic environments. These changes cause the declines of the water quality and pollution of the water. For these reasons, it is very important to analyze the physicochemical properties and heavy metal contents of the fresh water resources regularly for the monitoring the changes. Consequently, the existence of heavy metal pollution in aquatic environment leads to serious concerns about their influence on directly to the biota and indirectly to humans.

The aim of this study is to determine monthly changes of the heavy metal concentrations and physicochemical parameters of Çiğdem Pond (Kastamonu-Turkey). In the study area, no research work has been conducted on water quality parameters up to now. The results obtained from this study will contribute to the literature of the heavy metals and physicochemical parameters in the surface water sources and also serve as baseline data for future studies.

\section{Material and Methods}

\section{Study Area}

Çiğdem Pond $\left(41^{0} 34^{\prime} 50^{\prime \prime} N, 33^{0} 52^{\prime} 19^{\prime \prime} E\right)$ is located in Devrekani County of Kastamonu province. Pond was made of earthfill type and the land which has 3330 acres is irrigated via this pond. This pond has 0.923 $\mathrm{hm}^{3}$ of storage volume and the mean depth is around 5 to 6 meters. While determining the sampling stations on the pond, we consider the points that represent characteristics of the pond homogenously. $1^{\text {st }}$ station was located at the exit point of Çiğdem Pond (the deepest point of the Pond), $2^{\text {nd }}$ station at midpoint of the pond, and $3^{\text {rd }}$ station at entrance point of the Pond (Figure 1).

\section{Water Analysis}

This study was started in July 2015, samples used in analyses of some chemical and physical parameters constituting the water quality were monthly collected for 12 months from 3 stations, and the sampling was ended in June 2016.
Maintenance and cleaning of all the equipment to be used in field, field-type measurement devices, and glass sample tubes were completed 1 day before sampling process. The sampling tubes were sunk into acid solution, and then they are washed with pure water and dried in drying oven. The water samples were taken by shaking the sampling tubes and sinking them into $15 \mathrm{~cm}$ depth of water surface (Anonymous, 1998). The water samples have been taken to the laboratory within maximum 2 days for analysis. Temperature, $\mathrm{pH}$, salinity and electrical conductivity parameters were measured via field type devices in region. These parameters were measured via HACH LANGE brand HQ40D model digital two channel multiparameter.

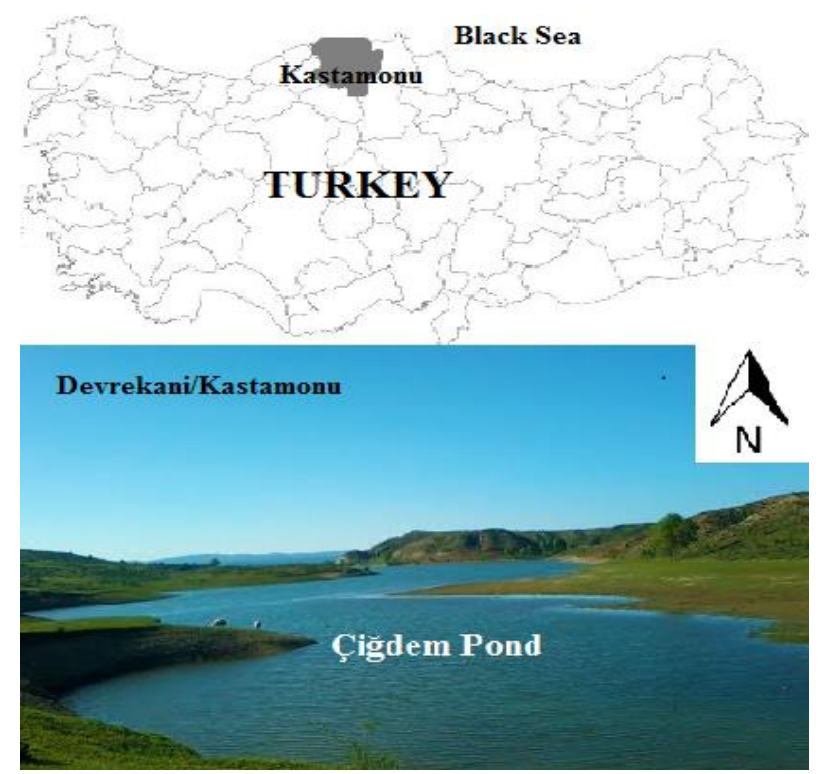

Figure 1 The location of sampling stations of Çiğdem Pond

The analyses of total alkalinity, total hardness, ammonium nitrogen, nitrate, nitrite, phosphate, sulfite, sulfate, potassium, chloride, sodium, suspended solid matter (SSM), chemical oxygen demand (COD), biological oxygen demand (BOD), calcium, magnesium, copper, zinc, ferrous, lead, nickel, mercury and cadmium of the water samples were performed in Kastamonu University Fisheries Faculty Laboratory in two days. Titration with sulfuric acid (for total alkalinity) and titration with EDTA (for total hardness) were performed. The results are presented in $\mathrm{mg} / \mathrm{L} \mathrm{CaCO}_{3}$ unit. The level of biological oxygen was calculated via HACH LANGE brand BOD TRAK II type manometric measurement device. Chemical oxygen level was calculated through titration with ferrous ammonium sulfate based on determining the amount of oxygen being used while lysing the natural and organic pollutant load by using powerful chemical oxidants. The analyses of nitrite, nitrate, ammoniac, ammonium nitrogen $\left(\mathrm{NH}_{4}{ }^{+}\right)$, chloride, phosphate, sulfate, sulfite, potassium, calcium, sodium and magnesium were conducted by using HACH LANGE brand DR 6000 laboratory type spectrophotometer (Mutlu et al., 2014). The analyses of the heavy metals such as lead, copper, ferrous and cadmium, mercury, nickel, and 
zinc of water samples were conducted using Shimadzu brand GCMS-QP2010 ULTRA type gas chromatographyMass Spectrometry in laboratory. The analysis of Suspended Solid Matter (SSM) was conducted by filtering the water through Whatman brand $42 \mathrm{Nr} 0.45$ $\mathrm{NM}$ membrane filters, and then keeping filter papers at $103^{\circ} \mathrm{C}$ for 24 hours and calculating the weight difference (Mutlu et al., 2014).

\section{Results and Discussion}

In this study, the physicochemical parameters were determined in the water samples monthly collected from 3 stations for 12 months (Table 1,2).

Water temperature is one of the most important factors that affect the biological activity of aquatic organisms. The mean values of temperature have non-significant variation between the stations in Çiğdem Pond (Table 1). As shown in Table 2, the lowest water temperature was $5.04^{\circ} \mathrm{C}$ in winter season while the highest water temperature was $19.14^{\circ} \mathrm{C}$ in autumn season. The annual mean temperature value was determined as $8.34^{\circ} \mathrm{C}$. These results show that the temperature differences were not at the level that can affect the aquatic life negatively.

The mean dissolved oxygen was lowest at the first station as $11.29 \mathrm{mg} / \mathrm{L}$, the overall mean values was ascertained as $11.30 \pm 1.71 \mathrm{mg} / \mathrm{L}$ in this Pond. The variations did not differ significantly across the stations (Table 1). Also, for spring, summer, autumn and winter seasons, the mean values of DO were found as 23.57, 20.37, 17.76 and $12.69 \mathrm{mg} / \mathrm{L}$, respectively (Table 2). In fresh waters, the dissolved oxygen shall be at least $5 \mathrm{mg} / \mathrm{L}$ for the sustainable aquatic life (Atay and Pulatsü, 2000). The results indicate that the water of the study area is suitable for aquaculture according to DO concentration, and it is in Class $\mathrm{I}(>8 \mathrm{mg} / \mathrm{L})$ according to SWQMR (Anonymous, 2015).

The hydrogen ion concentration of $\mathrm{pH}$ is a parameter that shows the chemical and biological characteristics and is used for classifying the alkalinity or acidity of waters. The mean $\mathrm{pH}$ ranged from 8.32 to 8.36 with in the stations with overall annual mean value of $8.34 \pm 0.14$ (Table 1). These results indicate that the significant change was not observed in the mean $\mathrm{pH}$ values between the stations and the seasons. In addition, drinking water $\mathrm{pH}$ level varies between 6.5 and 9.5. According to this information, the water of Çiğdem Pond is suitable for drinking in terms of $\mathrm{pH}$. In order for a water source to be suitable for aquaculture, the $\mathrm{pH}$ value shall vary between 6.5 and 8.5 (Kara and Gömlekçioğlu, 2004).These results indicate that the study area has basic character and is in Class I (between 6.5-8.5) (Anonymous, 2015) in terms of $\mathrm{pH}$ value and suitable for aquaculture.

Electrical conductivity (EC) is an important parameter for aquaculture. The mean values of EC have nonsignificant variation between the stations (Table 1). Also, the lowest value was $171.10 \mu \mathrm{s} / \mathrm{cm}$ in spring season while the highest value was $280.13 \mu \mathrm{s} / \mathrm{cm}$ in autumn season (Table 2). The annual mean EC value was calculated to be
$222.00 \mu \mathrm{s} / \mathrm{cm}$ and it is Class I $(<400 \mu \mathrm{s} / \mathrm{cm})$ according to SWQMR in terms of electrical conductivity.

Chemical Oxygen Demand (COD) is used to define the pollution level of waters (Mutlu et al., 2013). When the COD level of the waters higher than $25 \mathrm{mg} / \mathrm{L}$, it is show that the presence of pollution. Also, if the COD levels more than $50 \mathrm{mg} / \mathrm{L}$, it is indicate that the intense pollution and possible toxicity for aquatic organisms (Güler, 1997). The COD values of this study have shown insignificant variation (3.39-3.45 $\mathrm{mg} / \mathrm{L})$ within the stations. The minimum COD level was determines as 3.39 $\mathrm{mg} / \mathrm{L}$ in first and second stations, the maximum value was measured as $3.45 \mathrm{mg} / \mathrm{L}$ in third station (Table 1). The annual mean value was ascertained as $3.41 \mathrm{mg} / \mathrm{L}$ (Table 1). The seasonal changes of the mean COD values can be seen when analysing the Table 2. The maximum and minimum COD values were measured in summer and winter seasons as $4.83 \mathrm{mg} / \mathrm{L}$ and $1.73 \mathrm{mg} / \mathrm{L}$, respectively. These results indicate that the Çiğdem Pond is in Class I $(<25 \mathrm{mg} / \mathrm{L}$ ) in terms of COD (Anonymous, 2015).

Biological Oxygen Demand (BOD) indicates the oxygen amount required by the microorganisms. It is used for identifying the pollution potential and assimilation capacity of any receiver environment (Anonymous, 2013). BOD mean values of the study area within the stations varied from 1.37 to $1.43 \mathrm{mg} / \mathrm{L}$. The values show that it is not statistically significant variation within the stations (Table 1). Also, among the seasonal variation of the mean BOD levels, the minimum and maximum values were found to be 0.71 and $1.94 \mathrm{mg} / \mathrm{L}$ for winter and summer seasons, respectively (Table 2). The annual mean $\mathrm{BOD}$ value in Çiğdem Pond was determined to be 1.40 $\mathrm{mg} / \mathrm{L}$, and it is Class $\mathrm{I}(<4 \mathrm{mg} / \mathrm{L})$ in terms of BOD (Anonymous, 2015).

Suspended Solid (SS) are solid materials, consists of inorganic and organic matters such as clay and loam and affect aquatic life directly. High concentrations of suspended solids absorb the light and as a result of this situation, water quality can be impaired. Then, waters become warmer and the ability to hold oxygen of water, which is essential for aquatic life, decreases (Lawson, 2011). SS mean values for this study varied from 6.66 to $6.71 \mathrm{mg} / \mathrm{L}$ between the stations and the annual mean value was determined as $6.68 \mathrm{mg} / \mathrm{L}$ (Table 1) which is about 1.5 times lower than the maximum acceptable level of $10 \mathrm{mg} / \mathrm{L}$ for SS in aquaculture (Ntengwe, 2006). When examined the seasonal variations, the max and min mean values were found as $9.49 \mathrm{mg} / \mathrm{L}$ and $4.19 \mathrm{mg} / \mathrm{L}$ in autumn and winter seasons, respectively. According to these results, the conditions of Çiğdem pond in terms of SS are suitable for aquaculture.

Nitrogen derivatives of nitrite $\left(\mathrm{NO}_{2}\right)$, nitrate $\left(\mathrm{NO}_{3}\right)$ and ammonium nitrogen $\left(\mathrm{NH}_{4}{ }^{+}\right)$play important role in the process of water pollution. The nitrite $\left(\mathrm{NO}_{2}\right)$ sources in waters are the organic matters, fertilizers, and some of minerals. The nitrite concentration in surface waters higher than $1 \mathrm{mg} / \mathrm{L}$ indicates the presence of pollution (Taş, 2011). In Çiğdem Pond, $\mathrm{NO}_{2}$ mean values not varied between the stations and the annual mean value of $\mathrm{NO}_{2}$ was calculated as $0.003 \mathrm{mg} / \mathrm{L}$ (Table 1 ). It can be seen 
from the Table 2, the seasonal variation value were found as $0.0009 \mathrm{mg} / \mathrm{L}(\min )$ and $0.0052 \mathrm{mg} / \mathrm{L}(\max )$ in winter and summer seasons, respectively. Nitrate $\left(\mathrm{NO}_{3}\right)$ is the final product of nitrogenous organic matters. High concentration of nitrate in surface waters indicates the pollution. The nitrate $\left(\mathrm{NO}_{3}\right)$ sources in waters are the wastewaters, organic nitrogen and the fertilizers used in agriculture (Topal and Arslan Topal, 2012). It has been reported that fish mortality starts at $4 \mathrm{mg} / \mathrm{L}$ and higher doses (Acu, 2000). The nitrate mean values of the study area within the stations varied from 4.91 to $5.01 \mathrm{mg} / \mathrm{L}$ and the annual mean value was found to be $4.95 \mathrm{mg} / \mathrm{L}$. Also, among the seasonal variation of the mean $\mathrm{NO}_{3}$ levels, the minimum and maximum values were found to be 2.60 and $7.57 \mathrm{mg} / \mathrm{L}$ for winter and summer seasons, respectively (Table 2). The mean ammonium nitrogen (AN) values of the study area within the stations varied from 0.0003 to $0.0007 \mathrm{mg} / \mathrm{L}$, and the annual mean value was calculated as $0.0005 \mathrm{mg} / \mathrm{L}$. Among the seasonal variation of the mean AN levels, the min value was found to be 0.0003 $\mathrm{mg} / \mathrm{L}$ for winter season (Table 2). According to the SWQMR, the Çiğdem Pond has First Class water characteristic from the aspect of AN and nitrate and also has Second Class water characteristic in terms of nitrite (Anonymous, 2015).

Table 1 The annual mean values of the physicochemical parameters by the stations

\begin{tabular}{l|cccc}
\hline \multicolumn{1}{c|}{ Physicochemical Parameters } & Station 1 & Station 2 & Station 3 & AMV \\
\hline Dissolved Oxygen (DO) $(\mathrm{mg} / \mathrm{L})$ & $11.29 \pm 1.72$ & $11.31 \pm 1.72$ & $11.31 \pm 1.71$ & $11.30 \pm 1.71$ \\
Salinity & $0.07 \pm 0.03$ & $0.07 \pm 0.03$ & $0.16 \pm 0.29$ & $0.10 \pm 0.04$ \\
$\mathrm{pH}$ & $8.32 \pm 0.16$ & $8.36 \pm 0.17$ & $8.34 \pm 0.15$ & $8.34 \pm 0.14$ \\
Temperature $\left({ }^{\circ} \mathrm{C}\right)$ & $12.76 \pm 6.70$ & $12.67 \pm 6.71$ & $12.89 \pm 6.72$ & $12.77 \pm 6.71$ \\
Electrical Conductivity (EC) $(\mu \mathrm{s} / \mathrm{cm})$ & $221.96 \pm 53.79$ & $220.67 \pm 53.16$ & $223.37 \pm 54.04$ & $222.00 \pm 53.66$ \\
Suspended Solids $(\mathrm{SS})(\mathrm{mg} / \mathrm{L})$ & $6.66 \pm 2.93$ & $6.67 \pm 2.92$ & $6.71 \pm 2.94$ & $6.68 \pm 2.93$ \\
Chemical Oxygen Demand $(\mathrm{COD})(\mathrm{mg} / \mathrm{L})$ & $3.39 \pm 1.48$ & $3.39 \pm 1.53$ & $3.45 \pm 1.52$ & $3.41 \pm 1.51$ \\
Biological $\mathrm{Oxygen} \mathrm{Demand}(\mathrm{BOD})(\mathrm{mg} / \mathrm{L})$ & $1.37 \pm 0.57$ & $1.39 \pm 0.56$ & $1.43 \pm 0.58$ & $1.40 \pm 0.57$ \\
Chloride $\left(\mathrm{Cl}^{-1}\right)(\mathrm{mg} / \mathrm{L})$ & $4.25 \pm 1.22$ & $4.27 \pm 1.21$ & $4.30 \pm 1.20$ & $4.27 \pm 1.20$ \\
Phosphate $\left(\mathrm{PO} \mathrm{O}_{4}^{-3}\right)(\mathrm{mg} / \mathrm{L})$ & $0.218 \pm 0.166$ & $0.227 \pm 0.170$ & $0.227 \pm 0.169$ & $0.224 \pm 0.168$ \\
Sulphate $\left(\mathrm{SO}_{4}^{-2}\right)(\mathrm{mg} / \mathrm{L})$ & $53.93 \pm 9.00$ & $54.25 \pm 9.46$ & $54.81 \pm 9.78$ & $54.33 \pm 9.40$ \\
Sulphite $\left(\mathrm{SO}_{3}^{-2}\right)(\mathrm{mg} / \mathrm{L})$ & $1.58 \pm 0.37$ & $1.58 \pm 0.36$ & $1.62 \pm 0.39$ & $1.59 \pm 0.37$ \\
Sodium $(\mathrm{Na})(\mathrm{mg} / \mathrm{L})$ & $68.85 \pm 12.99$ & $68.94 \pm 13.01$ & $68.75 \pm 13.58$ & $68.85 \pm 13.17$ \\
Potassium $(\mathrm{K})(\mathrm{mg} / \mathrm{L})$ & $11.48 \pm 3.16$ & $11.54 \pm 3.21$ & $11.69 \pm 3.47$ & $11.57 \pm 3.28$ \\
Total Hardness $(\mathrm{TH})(\mathrm{mg} / \mathrm{L})$ & $303.73 \pm 21.92$ & $302.59 \pm 21.81$ & $304.54 \pm 21.89$ & $303.62 \pm 21.87$ \\
Total $\mathrm{Alkalinity}(\mathrm{TA})(\mathrm{mg} / \mathrm{L})$ & $318.40 \pm 22.15$ & $317.21 \pm 21.92$ & $319.46 \pm 21.99$ & $318.36 \pm 22.01$ \\
Magnesium $(\mathrm{Mg})(\mathrm{mg} / \mathrm{L})$ & $47.85 \pm 11.18$ & $47.79 \pm 11.33$ & $47.78 \pm 11.39$ & $47.81 \pm 11.29$ \\
Calcium $(\mathrm{Ca})(\mathrm{mg} / \mathrm{L})$ & $61.26 \pm 15.70$ & $61.54 \pm 15.73$ & $61.43 \pm 15.63$ & $61.41 \pm 15.68$ \\
Nitrite $\left(\mathrm{NO}_{2^{-}}\right)(\mathrm{mg} / \mathrm{L})$ & $0.003 \pm 0.002$ & $0.003 \pm 0.002$ & $0.003 \pm 0.002$ & $0.003 \pm 0.002$ \\
Nitrate $\left(\mathrm{NO}_{3}^{-}\right)(\mathrm{mg} / \mathrm{L})$ & $4.91 \pm 3.14$ & $4.94 \pm 3.15$ & $5.01 \pm 3.20$ & $4.95 \pm 3.17$ \\
Ammonium $\mathrm{Nitrogen}(\mathrm{AN})(\mathrm{mg} / \mathrm{L})$ & $0.0003 \pm 0.0002$ & $0.0004 \pm 0.0003$ & $0.0007 \pm 0.0006$ & $0.0005 \pm 0.0003$ \\
\hline
\end{tabular}

AMV: Annual Mean Value

Table 2 The seasonal variations of the physicochemical parameters

\begin{tabular}{l|cccc}
\hline \multicolumn{1}{c|}{ Physicochemical parameters } & Spring & Summer & Autumn & Winter \\
\hline Dissolved Oxygen $(\mathrm{DO})(\mathrm{mg} / \mathrm{L})$ & $23.57 \pm 0.22$ & $20.37 \pm 1.85$ & $17.76 \pm 1.20$ & $12.69 \pm 0.06$ \\
Salinity & $0.051 \pm 0.015$ & $0.191 \pm 0.207$ & $0.108 \pm 0.025$ & $0.048 \pm 0.017$ \\
$\mathrm{pH}$ & $8.28 \pm 0.05$ & $8.43 \pm 0.07$ & $8.44 \pm 0.21$ & $8.21 \pm 0.07$ \\
Temperature $\left({ }^{\circ} \mathrm{C}\right)$ & $9.44 \pm 3.12$ & $17.46 \pm 3.86$ & $19.14 \pm 4.52$ & $5.04 \pm 1.61$ \\
Electrical Conductivity (EC) $(\mu \mathrm{s} / \mathrm{cm})$ & $171.10 \pm 19.07$ & $250.63 \pm 40.71$ & $280.13 \pm 36.29$ & $186.14 \pm 19.63$ \\
Suspended Solids $(\mathrm{SS})(\mathrm{mg} / \mathrm{L})$ & $4.51 \pm 0.76$ & $8.53 \pm 2.74$ & $9.49 \pm 2.17$ & $4.19 \pm 1.01$ \\
Chemical Oxygen Demand (COD) $(\mathrm{mg} / \mathrm{L})$ & $3.35 \pm 1.56$ & $4.83 \pm 1.28$ & $3.72 \pm 0.87$ & $1.73 \pm 0.59$ \\
Biological $\mathrm{Oxygen}$ Demand $(\mathrm{BOD})(\mathrm{mg} / \mathrm{L})$ & $1.18 \pm 0.57$ & $1.94 \pm 0.20$ & $1.76 \pm 0.16$ & $0.71 \pm 0.08$ \\
Chloride $\left(\mathrm{Cl}^{-1}\right)(\mathrm{mg} / \mathrm{L})$ & $3.60 \pm 0.77$ & $4.98 \pm 0.09$ & $5.15 \pm 0.14$ & $3.36 \pm 1.89$ \\
Phosphate $\left(\mathrm{PO} \mathrm{O}_{4}^{-3}\right)(\mathrm{mg} / \mathrm{L})$ & $0.087 \pm 0.046$ & $0.226 \pm 0.061$ & $0.384 \pm 0.168$ & $0.198 \pm 0.230$ \\
Sulphate $\left(\mathrm{SO}_{4}^{-2}\right)(\mathrm{mg} / \mathrm{L})$ & $52.12 \pm 2.34$ & $67.12 \pm 5.12$ & $51.07 \pm 7.91$ & $47.01 \pm 6.54$ \\
Sulphite $\left(\mathrm{SO}_{3}^{-2}\right)(\mathrm{mg} / \mathrm{L})$ & $1.91 \pm 0.31$ & $1.84 \pm 0.17$ & $1.33 \pm 0.24$ & $1.29 \pm 0.31$ \\
Sodium $(\mathrm{Na})(\mathrm{mg} / \mathrm{L})$ & $77.18 \pm 13.50$ & $79.46 \pm 14.94$ & $58.12 \pm 0.75$ & $60.63 \pm 1.33$ \\
Potassium $(\mathrm{K})(\mathrm{mg} / \mathrm{L})$ & $12.34 \pm 2.11$ & $14.22 \pm 5.56$ & $9.06 \pm 0.06$ & $10.66 \pm 1.28$ \\
Total $\mathrm{Hardness}(\mathrm{TH})(\mathrm{mg} / \mathrm{L})$ & $296.45 \pm 10.73$ & $327.27 \pm 4.79$ & $312.62 \pm 21.60$ & $278.13 \pm 3.66$ \\
Total $\mathrm{Alkalinity}(\mathrm{TA})(\mathrm{mg} / \mathrm{L})$ & $311.35 \pm 11.30$ & $342.06 \pm 5.26$ & $327.35 \pm 21.64$ & $292.68 \pm 3.89$ \\
Magnesium $(\mathrm{Mg})(\mathrm{mg} / \mathrm{L})$ & $38.47 \pm 4.44$ & $58.00 \pm 5.92$ & $56.06 \pm 2.90$ & $38.69 \pm 11.17$ \\
Calcium $(\mathrm{Ca})(\mathrm{mg} / \mathrm{L})$ & $61.23 \pm 14.56$ & $76.52 \pm 16.33$ & $62.73 \pm 2.83$ & $45.16 \pm 11.13$ \\
Nitrite $\left(\mathrm{NO}_{2^{-}}\right)(\mathrm{mg} / \mathrm{L})$ & $0.0040 \pm 0.0007$ & $0.0052 \pm 0.0021$ & $0.0029 \pm 0.0004$ & $0.0009 \pm 0.0006$ \\
Nitrate $\left(\mathrm{NO}_{3}^{-}\right)(\mathrm{mg} / \mathrm{L})$ & $5.89 \pm 2.45$ & $7.57 \pm 4.85$ & $3.75 \pm 0.72$ & $2.60 \pm 1.75$ \\
Ammonium $\mathrm{Nitrogen}(\mathrm{AN})(\mathrm{mg} / \mathrm{L})$ & $0.0006 \pm 0.0002$ & $0.0006 \pm 0.0003$ & $0.0004 \pm 0.0003$ & $0.0003 \pm 0.0005$ \\
\hline
\end{tabular}


The phosphate in water resources is necessary for aqualic life (Harper, 1992). The reason of fluctuation in phosphate level is the use of agricultural fertilizers containing phosphate. The highest mean value was observed in autumn season as $0.384 \mathrm{mg} / \mathrm{L}$, while the lowest mean value was determined in spring season as $0.087 \mathrm{mg} / \mathrm{L}$ (Table 2) and annual mean was ascertained as $0.224 \mathrm{mg} / \mathrm{L}$ (Table 1). The phosphate, one of the nutrient minerals affecting the productivity of aquatic life, showed increase in summer and autumn months. This phosphate concentration indicates that the water of Çiğdem Pond is in Class III in accordance with SWQMR (Anonymous, 2015). Among natural anions in the water, the presence of the sulphate $\left(\mathrm{SO}_{4}\right)$ is important for the improved biological productivity (Taş et al., 2010). The maximum limit for sulphate in water for aquatic products has been determined as $90 \mathrm{mg} / \mathrm{L}$ (Küçük, 2007). The sulphate value of Çiğdem Pond showed insignificantly differences between stations. The maximum value was found as 54.81 $\mathrm{mg} / \mathrm{L}$ in 3rd station, while the minimum was observed as $53.93 \mathrm{mg} / \mathrm{L}$ in 1 st station and the annual mean value was ascertained to be $54.33 \mathrm{mg} / \mathrm{L}$ (Table 1). The seasonal mean values of sulphate were $52.12 \mathrm{mg} / \mathrm{L}, 67.12 \mathrm{mg} / \mathrm{L}$, $51.07 \mathrm{mg} / \mathrm{L}$ and $47.01 \mathrm{mg} / \mathrm{L}$ for spring, summer, autumn and winter, respectively (Table 2). All these values are lower than the maximum acceptable level of $90 \mathrm{mg} / \mathrm{L}$ for sulphate in water for aquatic products. Also the chloride level is an important indicator for the water quality. The highest mean chloride value was observed in autumn season as $5.15 \mathrm{mg} / \mathrm{L}$, while the lowest was recorded as $3.36 \mathrm{mg} / \mathrm{L}$ in winter season. The annual mean value was determined as $4.27 \mathrm{mg} / \mathrm{L}$. In addition, the sulphite mean values for the area under investigation varied from 1.58 to $1.62 \mathrm{mg} / \mathrm{L}$ between the stations and the annual mean value was determined as $1.59 \mathrm{mg} / \mathrm{L}$. Within the seasonal variation, the max and min mean values were found as
$1.91 \mathrm{mg} / \mathrm{L}$ and $1.29 \mathrm{mg} / \mathrm{L}$ in spring and winter seasons, respectively (Table 2). As a result of these data, it can be said that the Çiğdem Pond is suitable for aquaculture.

Calcium $(\mathrm{Ca})$ and Magnesium $(\mathrm{Mg})$ are the most important alkali soil minerals in fresh water (Mutlu et al., 2013). The max recommended level of $\mathrm{Ca}$ is reported to be $75 \mathrm{mg} / \mathrm{L}$ (Taş, 2006). The annual mean Ca level was found to be $61.41 \mathrm{mg} / \mathrm{L}$ in Çiğdem Pond. This calcium concentration indicates that the annual mean value is 1.2 times lower than the acceptable limits. Also, within the seasonal variation, the max mean value was found to be $76.52 \mathrm{mg} / \mathrm{L}$ in summer season, and the min mean value was found to be $45.16 \mathrm{mg} / \mathrm{L}$ in winter season. This $\max$ value is nearly same with the max acceptable level of $\mathrm{Ca}$, while the min value is about 1.7 times lower than the acceptable level. The level of $\mathrm{Mg}$ in normal waters should vary from $5 \mathrm{mg} / \mathrm{L}$ to $60 \mathrm{mg} / \mathrm{L}$. In mildly hard waters, the values between 60 and $100 \mathrm{mg} / \mathrm{L}$ can be accepted as typical, and the recommended concentration of $\mathrm{Mg}$ is 50 $\mathrm{mg} / \mathrm{L}$ (Taş, 2006). In this study, the annual mean value was determined as $47.81 \mathrm{mg} / \mathrm{L}$ and this value is nearly same with the recommended value. The $\mathrm{Mg}$ mean values in Çiğdem pond showed non-significant variance between the stations (Table 1). The concentration of Sodium (Na) and Potassium $(\mathrm{K})$ vary within the ranges of $2-100 \mathrm{mg} / \mathrm{L}$ and $1-10 \mathrm{mg} / \mathrm{L}$ in natural waters, respectively (Boyd, 1998). The annual mean $\mathrm{K}$ level in this study was 11.57 $\mathrm{mg} / \mathrm{L}$ and this level is higher than the normal ranges. But the annual mean level of $\mathrm{Na}$ concentration was found to be $68.85 \mathrm{mg} / \mathrm{L}$ that can be considered to be within the normal ranges in natural waters.

The distribution of some of the physicochemical parameters in Çiğdem Pond is given in Figure 2. In this study, the heavy metal concentrations of the water samples collected from the study area were ascertained (Table 3, 4).

Table 3 The annual mean values of the heavy metal concentrations by the stations

\begin{tabular}{|c|c|c|c|c|}
\hline Heavy Metal Concentrations $(\mu \mathrm{g} / \mathrm{L})$ & Station 1 & Station 2 & Station 3 & AMV \\
\hline  & $2 \pm 1$ & $2 \pm 1$ & $3 \pm 2$ & $2 \pm 1$ \\
\hline $\mathrm{Pb}$ & $0.91 \pm 0.41$ & $1.03 \pm 0.46$ & $1.13 \pm 0.44$ & $1.02 \pm 0.43$ \\
\hline $\mathrm{Cu}$ & $6 \pm 3.36$ & $6.92 \pm 3.73$ & $7.33 \pm 3.94$ & $6.75 \pm 3.66$ \\
\hline $\mathrm{Cd}$ & $0.23 \pm 0.16$ & $0.29 \pm 0.16$ & $0.31 \pm 0.15$ & $0.28 \pm 0.15$ \\
\hline $\mathrm{Hg}$ & $0.006 \pm 0.003$ & $0.006 \pm 0.004$ & $0.007 \pm 0.004$ & $0.006 \pm 0.004$ \\
\hline $\mathrm{Ni}$ & $0.75 \pm 0.97$ & $0.92 \pm 1.24$ & $2.31 \pm 3.58$ & $1.33 \pm 1.49$ \\
\hline $\mathrm{Zn}$ & $9.50 \pm 6.91$ & $10.58 \pm 7.08$ & $11.00 \pm 7.01$ & $10.36 \pm 6.99$ \\
\hline
\end{tabular}

AMV: Annual Mean Value $(\mu \mathrm{g} / \mathrm{L})$

Table 4 The seasonal variations of the heavy metal concentrations

\begin{tabular}{|c|c|c|c|c|}
\hline Heavy Metal concentrations $(\mu \mathrm{g} / \mathrm{L})$ & Spring & Summer & Autumn & Winter \\
\hline $\mathrm{Fe}$ & $3 \pm 1$ & $2 \pm 1$ & $3 \pm 2$ & $1 \pm 1$ \\
\hline $\mathrm{Pb}$ & $1.22 \pm 0.13$ & $1.29 \pm 0.71$ & $0.77 \pm 0.32$ & $0.81 \pm 0.25$ \\
\hline $\mathrm{Cu}$ & $7.6 \pm 3.50$ & $9.8 \pm 4.55$ & $6.4 \pm 2.34$ & $3.23 \pm 1.37$ \\
\hline $\mathrm{Cd}$ & $0.18 \pm 0.02$ & $0.42 \pm 0.04$ & $0.37 \pm 0.20$ & $0.14 \pm 0.05$ \\
\hline $\mathrm{Hg}$ & $0.005 \pm 0.003$ & $0.010 \pm 0.003$ & $0.007 \pm 0.002$ & $0.003 \pm 0.001$ \\
\hline $\mathrm{Ni}$ & $0 \pm 0$ & $0.78 \pm 0.69$ & $2.44 \pm 1.17$ & $2.08 \pm 2.12$ \\
\hline $\mathrm{Zn}$ & $9.56 \pm 6.85$ & $17.00 \pm 7.02$ & $11.00 \pm 6.11$ & $3.89 \pm 2.17$ \\
\hline
\end{tabular}


The presence of four essential micronutrients $(\mathrm{Cu}, \mathrm{Fe}$, $\mathrm{Ni}$ and $\mathrm{Zn}$ ) was detected in the water samples (Table 3). $\mathrm{Cu}, \mathrm{Fe}, \mathrm{Ni}$ and $\mathrm{Zn}$ are essential metals in the human body, but if the body takes excessive these elements from the outside environment, they will damage health. In this study, the mean concentrations were ranged 6.00-7.33, 2.00-3.00, 0.75-2.31 and 9.50-11.00 $\mu \mathrm{g} / \mathrm{L}$ within the stations, respectively. The annual mean values for these elements were calculated as 6.75, 2.00, 1.33 and 10.36 $\mu \mathrm{g} / \mathrm{L}$, respectively. Because of the use of ferrouscontaining agricultural pesticides increases especially spring season, the ferrous-containing waters can penetrate into the pond through the rain waters. The mean concentration of ferrous in autumn and spring seasons was calculated to be $3 \mu \mathrm{g} / \mathrm{L}$, and this value is higher than the mean values of the other seasons. In addition, many foodstuffs and waters contain certain amounts of $\mathrm{Zn}$ and also industrial sources may cause the concentrations of $\mathrm{Zn}$ in drinking water to reach levels that can cause health problems. The annual mean $\mathrm{Zn}$ concentrations of 10.36 $\mu \mathrm{g} / \mathrm{L}$ (Table 3 ) were below the maximum contamination level (MCL) of $5 \mathrm{mg} / \mathrm{L}$ recommended by Anonymous (Anonymous, 2010). Fe is an important metal for plants, animals and humans, especially in the cellular processes. $\mathrm{Fe}$ is found in natural fresh water but have no healthbased guideline value, although high concentrations (above $0.3 \mathrm{mg} / \mathrm{l}$ ) give rise to consumer complaints (Anonymous, 2014). In this study annual mean Fe concentration was found to be $2 \mu \mathrm{g} / \mathrm{L}$ and the value is lower than the maximum contaminant level (MCL) of $<0.3 \mathrm{mg} / \mathrm{L}$ (Anonymous, 2010).

The annual mean concentration of the copper $(\mathrm{Cu})$ and nickel (Ni) were calculated to be 6.75 and $1.33 \mu \mathrm{g} / \mathrm{L}$, respectively. The mean concentration of $\mathrm{Cu}$ in spring and summer seasons are 7.6 and $9.8 \mu \mathrm{g} / \mathrm{L}$, and these values are higher than the mean values of the autumn and winter seasons. The reason for this is believed to be the penetration of copper, which accumulate in the soil due to common use of copper vitriol during maintenance and pruning in fruit gardens, into the pond via the rain waters. The mean concentration of $\mathrm{Ni}$ in autumn and winter seasons are 2.844 and $2.08 \mu \mathrm{g} / \mathrm{L}$, and these values are higher than the other seasons. The maximum mean concentration of Zinc ( $\mathrm{Zn}$ ) was found to be $11.00 \mu \mathrm{g} / \mathrm{L}$ in $3^{\text {rd }}$ station and the annual mean value was found as 10.36 $\mu \mathrm{g} / \mathrm{L}$. In summer season, the mean concentration of $\mathrm{Zn}$ is higher than the other seasons to be $17.00 \mu \mathrm{g} / \mathrm{L}$. In the light of all this information, it can be said that the Çiğdem Pond has Class I water characteristic in terms of ferrous $(\mathrm{Fe})$, copper $(\mathrm{Cu})$, nickel $(\mathrm{Ni})$ and zinc $(\mathrm{Zn})$, according to SWQMR (Anonymous, 2015).

Besides the essential micronutrients, the presence of three toxic heavy metals $(\mathrm{Pb}, \mathrm{Cd}$ and $\mathrm{Hg}$ ) was detected in the study area in the range of $0.91-1.13,0.23-0.31$ and $0.006-0.007 \mu \mathrm{g} / \mathrm{L}$ between the stations. The annual mean values were found to be $1.02,0.28$ and $0.006 \mu \mathrm{g} / \mathrm{L}$, respectively (Table 3 ). The seasonal mean concentrations of these metals were determined as $1.22,0.18$, and 0.005 $\mu \mathrm{g} / \mathrm{L}$ for the spring season, $1.29,0.42$, and $0.010 \mu \mathrm{g} / \mathrm{L}$ for the summer season, $0.77,0.37$ and $0.007 \mu \mathrm{g} / \mathrm{L}$ for the autumn season and $0.81,0.14$ and $0.003 \mu \mathrm{g} / \mathrm{L}$ for the winter season, respectively (Table 4). The seasonal variations of the heavy metals are given in Figure 3. The lead $(\mathrm{Pb})$ concentration of $0.01 \mathrm{mg} / \mathrm{L}$ and higher are considered to be an indicator of polluted water. Although the presence of cadmium $(\mathrm{Cd})$ in waters at the concentration of $5 \mu \mathrm{g} / \mathrm{L}$ and higher has been reported to be toxic, and it directly leads to mortality in aquatic organisms (Mutlu et al., 2013). The annual mean value of $\mathrm{Pb}$ and $\mathrm{Cd}$ in Çiğdem Pond were found to be $1.02 \mu \mathrm{g} / \mathrm{L}$ and $0.28 \mu \mathrm{g} / \mathrm{L}$, respectively and these values are lower than the recommended contamination levels. These levels of $\mathrm{Cd}$ and $\mathrm{Pb}$ can be attributed to the use of artificial phosphate fertilizers for the agricultural purposes around the pond. Also the mercury $(\mathrm{Hg}$ ) concentration may be caused from the flows from cultivation areas into the pond, since the use of fertilizers is very common around the studied area. According to these findings, it is said that the studied surface water has Class I water characteristics from the aspect of $\mathrm{Pb}, \mathrm{Cd}$ and $\mathrm{Hg}$ according to SWQMR (Anonymous, 2015).

\section{Conclusion}

The physicochemical parameters and the heavy metal concentrations in water samples of Çiğdem Pond were ascertained in this study. The heavy metals an important pollutant group and these pollutants accumulate within the bodies of living organisms, and also they have significant toxic and carcinogenic effects. As it can be seen in results obtained in this study, the water quality in Çiğdem Pond is considered to be Class I according to SWQMR. To protect the water quality and to ensure the health of aquatic life in this pond, it is required to make regular observations and to monitor the parameters affecting the water quality and aquatic life. Also, the results of the present study useful in assessment of the water quality parameters and will be valuable database for future estimations of the impact of the water pollution.

\section{Acknowledgements}

The authors are thankful to Republic of Turkey, Ministry of Forestry and Water Affairs, District 10 Office, Kastamonu provincial branch directorate's staff for support and cooperation.

\section{References}

Acu A. 2000. Beytepe Göleti' nin Su Kalitesinin Belirlenmesi Üzerine Bir Araştırma. Postgraduate Thesis, Department of Aquaculture, Science Institute of Ankara University, AnkaraTurkey.

Anonymous. 1998. Standard methods for the examination of water and wastewater. American Public Health Association, 7th Edition, Washington, USA.

Anonymous. 2010. United States Environmental Protection Agency (USEPA). List of contaminants and their maximum contaminant level (MCLs), URL: http://water.epa.gov/drink/contaminants/ index.cfm \#List. Accessed on 26-12-2010. 
Anonymous. 2013. TR Ministry of Forestry and Water Affairs, Water Quality Management Workgroup Report. Convention of Forestry and Water, $21^{\text {st }}-23^{\text {rd }}$.

Anonymous. 2014. World Health Organization (WHO). Guidelines for drinking water quality, 3rd edn., World Health Organization, Geneva.

Anonymous. 2015. Surface Water Quality Management Regulation. TR Official Gazette Nr.29327, Ankara (in Turkish).

Asaolu SS, Ipinmoroti KO, Adeyinowo CE, Olaofe O. 1997. Interrelationship of heavy metals concentration in water, sediment as fish samples from Ondo State coastal Area, Nig. Afr. J. Sci. 1, 55.

Atay D, Pulatsü S. 2000. Su Kirlenmesi ve Kontrolu. Faculty of Agriculture, Ankara University, Publication Nr.1513, Ankara.

Boyd CE. 1998. Water Quality for Pond Aquaculture. Alabama Agricultural Experiment Station, Research and Development Series, No: 43, Auburn-USA.

Debels P, Figueroa R, Urrutia R, Barra R, Niell X. 2005. Evaluation of Water Quality in The Chilla'N River (Central Chile) Using Physicochemical Parameters and A Modifiedwater Quality Index. Environ. Monit. Assess. 110, 301.

Güler Ç. 1997. Water Quality and Environmental Health of the Source Array. 43, 95, Ankara.

Harper D. 1992. Eutrophication of Freshwaters: Principles, Problems and Restoration London, Chapyen Hall. p. 78.

Kara C, Gömlekçioğlu V. 2004. Karaçay (Kahramanmaraş) 'in Kirliliğinin Biyolojik ve Fiziko-Kimyasal Parametrelerle İncelenmesi. Kahramanmaraş Sütçü İmam University, Journal of Science and Engineering. 7,1-7.

Khan S, Shahnaz M, Jehan N, Rehman S, Shah MT, Din I. 2013. Drinking water quality and human health risk in Charsadda district, Pakistan. Journal of Cleaner Production, 60, 93-101.

Kutlu B, Sesli A, Tepe R, Mutlu E. 2015. Assessment of Physicochemical Water Quality of Birecik Dam, Şanlıurfa, Southeastern Anatolia Region, Turkey. Turkish Journal of Agriculture - Food Science and Technology, 3(7), 623-628.

Küçük S. 2007. Investigation of Water of Quality Parameters of the Buyuk Menderes River for Fisheries. J. Adnan Menderes University Agricultural Faculty, 4(1-2), 7-13 (in Turkish).

Lawson EO. 2011. Physico-Chemical Parameters and Heavy Metal Contents of Water from the Mangrove Swamps of Lagos Lagoon, Lagos, Nigeria. Advances in Biological Research, 5(1), 8-21.
Mutlu E, Kutlu B, Demir T. 2014. Investigation the water quality of Çimenyenice Lake (Hafik- Sivas). Journal of Selçuk University Natural and Applied Science, Online ISSN: 2147-3781, 11291143.

Mutlu E, Yanık T, Demir T. 2013. Horohon Deresi (Hafik-Sivas)' nin $\mathrm{Su}$ Kalitesi Özelliklerinin Aylık Değişimleri. Alınteri Agricultural Sciences Journal, 25, 45-57.

Ntengwe FW. 2006. Pollutant loads and water quality in Streams of heavily populated and industrialised towns. Physics and Chemistry of the Earth, 31, 832-839.

Papafilippaki AK, Kotti ME, Stavroulakis GG. 2008. Seasonal Variations in Dissolved Heavy Metals in The Keritis River, Chania, Greece. Global NEST J., 10, 3, 320.

Shehu A, Vasjari M, Baraj E, Lilo R, Allabashi R. 2016. Contamination Status of Erzeni River, Albania due to Heavy Metals Spatial and Temporal Distribution. Fresenius Environmental Bulletin, 25(2), 525-533.

Taş B. 2006. Derbent Baraj Gölü (Samsun) Su Kalitesinin Incelenmesi. Ekoloji, 15, 6-15.

Taş B. 2011. Gaga Gölü (Ordu,Turkey) Su Kalitesinin İncelenmesi. Black Sea Technical University's Journal of Science, 1(3), 4361.

Taş B, Candan AY, Can ÖV, Topkara S. 2010. Ulugöl (ORDU)'nun Bazı Fiziko-Kimyasal Özellikleri. Journal of Fisheries Sciences, 4(3), 254-263.

Taş B, Yılmaz Ö. 2015. Cimil Deresi (Rize, Türkiye)'nin Epilitik Alg Çeşitliliği. Türk Tarım - Gıda Bilim ve Teknoloji Dergisi, 3(10), 826-833.

Topal M, Arslan Topal E. 2012. Elazığ ilinde Bir Maden Sahasında Kaynaklanan Sızıntı Sularının Maden Çayına Etkisi. Karaelmas University, Journal of Science and Engineering, 2(1), 15-21.

USDA (United States Department of Agriculture). 2000. Heavy Metal Soil Contamination. Natural Resources Conservation Service, Soil Quality-Urban Technical Note No. 3, September.

Wu G, Zhang Q, Zheng X, Mu L, Dai L. 2008. Water quality of Lugu Lake: Changes, causes and measurements. International Journal of Sustainable Development and World Ecology, 15, 10-17. 